\title{
Scavenging behaviour by Ergalatax contractus (Gastropoda: Muricidae) and interactions with Nassarius nodifer (Gastropoda: Nassariidae) in the Cape d'Aguilar Marine Reserve, Hong Kong
}

\author{
Brian Morton \\ The Swire Institute of Marine Science, The University of Hong Kong, Cape d’Aguilar, Shek O, Hong Kong. \\ Present address: Department of Zoology, The Natural History Museum, Cromwell Road, London, SW7 5BD, UK. \\ E-mail: prof_bsmorton@hotmail.com
}

\begin{abstract}
Aspects of the feeding behaviour of Ergalatax contractus (Muricidae) were studied. Field experiments demonstrated that large numbers of individuals of this species, comprising $\sim 90 \%$ of a suite of gastropod scavengers, were attracted to baited traps in the subtidal sands of Lobster Bay, Cape d'Aguilar Marine Reserve, Hong Kong. Laboratory experiments identified the effective chemo-detection distances of E. contractus as $60 \mathrm{~cm}$ in still and $>80 \mathrm{~cm}$ in flowing water, respectively. The average times to arrival at bait in still and flowing water were 92.3 and $69.0 \mathrm{~min}$, respectively, but were significantly less for individuals experiencing a longer period of starvation. The mean time taken for E. contractus to consume a meal was $70.6 \mathrm{~min}$.

Comparisons were made between Ergalatax contractus and Nassarius nodifer, representative of a suite of sympatric scavenging nassariids in Lobster Bay. The nassariid arrived significantly faster at bait in both still (30.2 $\mathrm{min})$ and flowing water $(20.8 \mathrm{~min})$ than E. contractus and fed faster $(25.7 \mathrm{~min})$, as is typical of representatives of the Nassariidae. Although the two species partition carrion resources temporally, manipulation experiments provided evidence for inter-specific competition between them. That is, although E. contractus possesses the morphological and behavioural characteristics of a predator, its opportunistic scavenging abilities have led to its success and numerical superiority on the shallow subtidal sands of Lobster Bay. The dominance of E. contractus in Lobster Bay, and elsewhere in Hong Kong, is unusual. Here, the normally predatory E. contractus, far outnumbers all other scavengers, possibly because of an enhanced, largely allochthonous, supply of food which it is able to exploit by virtue of its previously identified opportunistic habit of scavenging the leftovers of other predators. The presence of inter-specific competition between E. contractus and a sympatric suite of nassariids enhances, not impedes, carrion exploitation.
\end{abstract}

\section{INTRODUCTION}

The Muricidae is one of the largest families of carnivorous marine gastropods (Ponder, 1973; Boss, 1982). Members of this family of predators occupy keystone positions on rocky shores worldwide, their shell drilling abilities enabling them to attack many species (Taylor, 1976, 1998; Taylor \& Morton, 1996; Morton \& Harper, 1997). Toxic hypobranchial secretions are sometimes used to immobilize prey, and sessile biota are accessed typically by drilling straight-sided holes through the shells by which tissues are eaten (Carriker, 1981). Most species are regarded as generalist predators especially on herbivorous gastropods that have limited powers of locomotion, such as limpets, and sessile suspension feeding bivalves, such as mussels and barnacles (Taylor, 1976, 1984; Morton, 1994). There are many exceptions to this generalization (Moran et al., 1984; Taylor, 1984; Vermeij et al., 1994) and in different habitats, some species, for example, Lepsiella vinosa in southern Australia, demonstrate 'prey switching' (Bayliss, 1982). A flexible diet can also be inferred from an ability to switch between prey species with respect to their natural availability (Nickell \& Moore, 1992a; Morton et al., 2002). Muricids thus show various adaptations to obtain nutrition in different habitats by using different foraging strategies (Vermeij et al., 1994).

Taylor (1980, 1982), Taylor \& Morton (1996) and Harper \& Morton (1997) have reviewed feeding behaviours of Hong Kong muricids on exposed rocky shores. The most common species, including Thais clavigera, Thais luteostoma and Morula musiva, mainly feed on gastropods. The diets of these species vary spatially, however, and T. clavigera may also change its diet temporally. Lower shore species such as Cronia margariticola, mainly prey on polychaetes. Engina armillata and Mitra scutulata are specialist predators of serpulid polychaetes (Tan \& Morton, 1998) and sipunculans (Taylor, 1998), respectively. A diverse assemblage of muricids is present in the Cape 
d'Aguilar Marine Reserve. Thais clavigera is the dominant predator on exposed rocky shores but Morula musiva, C. margariticola and Ergalatax contractus (Reeve, 1846) also contribute to the intertidal predator community whereas T. luteostoma, Engina armillata and Chicoreus microphyllus are more common on the rocky subtidal (Morton \& Harper, 1997). In Cape d'Aguilar and elsewhere, Ergalatax contractus preys on intertidal mussels, barnacles and polychaetes and on subtidal oysters (Taylor, 1980; Taylor \& Morton, 1996; Ishida, 2001).

Representatives of the Nassariidae mainly comprise scavengers (Morton \& Britton, 1991; Britton \& Morton, 1994a,b). Britton \& Morton (1994b, p. 375) described nassariids as the 'closest of all marine organisms to obligate scavengers'. Representatives have a worldwide distribution on the seabed and on soft shores, being most common in protected embayments in the tropics and subtropics. Most research on the Nassariidae has focused on intertidal species that are well adapted to scavenging. Deeper water species are less well studied (Morton \& Britton, 1993; Britton \& Morton, 1994b). Intertidal representatives of the Nassariidae are well equipped for a scavenging mode of life. They have acute distance chemo-detection abilities, as do species of Muricidae (Kohn, 1961), and some can identify carrion over many metres, that is, $>200 \mathrm{~m}$ for both Nassarius clarus and Nassarius dorsatus in northwestern Western Australia (Morton, 2003; Morton \& Britton, 2003). The most common subtidal species in Hong Kong, Nassarius siquijorensis, is less efficient (Liu \& Morton, 1994a; Britton \& Morton, 1994b; Morton \& Chan, 1999). Nassariids track carrion in numbers, feed fast and leave it upon satiation (Britton \& Morton, 1992; Morton \& Britton, 1993). They are also capable of surviving without food for long periods (Britton \& Morton, 1993, 1994a), for example, >100 days in the case of Nassarius festivus (Morton, 1990).

Nassariids are important cleaners of Hong Kong's marine ecosystem (Liu \& Morton, 1994a) and the sandy shore species Nassarius festivus is the best studied (Morton, 1990; Britton \& Morton, 1992; Cheung, 1994; Morton \& Chan, 1999, 2003, 2004; Chan \& Morton, 2005). It has the typical behaviour of a scavenger, with acute distance chemo-detection, fast locomotion and rapid consumption. A number of subtidal nassariids have been recorded from an earlier survey of the subtidal sands of Lobster Bay and include Nassarius nodifer, Nassarius reeveanus, Nassarius glans and Nassarius albescens (Morton \& Harper, 1997). Later research by Morton \& Chan (2000), however, also recorded Nassarius crematus, $\mathcal{N}$. reeveanus and Nassarius pauperus as attracted to baited traps in the bay. Nassariid numbers were, however, shown by the above authors to be minor in comparison with the overwhelming dominance exhibited by Ergalatax contractus. A greater recent interest in the subtidal benthos of Hong Kong (Leung \& Morton, 2003) has also demonstrated that far from being solely a rocky intertidal polychaete predator (Taylor, 1982; Taylor \& Morton, 1996; Harper \& Morton, 1997), $E$. contractus is widespread and numerous all over the shallow inshore seabed (down to $-30 \mathrm{~m}$ chart datum). Moreover, initial research by Morton \& Chan (2000) suggested that subtidally $E$. contractus behaved as a scavenger, similar to nassariids. There are three other reports, from Japan, of the strong inclination by
E. contractus for scavenging (Takashi, 2000; Ishida, 2001, 2004). It therefore seems likely that $E$. contractus is not only adept at prey switching, but is also highly opportunistic and can readily exploit carrion when it is available.

The Cape d'Aguilar Marine Reserve, embracing its focus of Lobster Bay, is situated on the south-eastern most tip of Hong Kong Island. The topography of the reserve is described by Morton \& Harper (1995, figure 3). Given that macrophagous scavenging is not a common phenomenon among marine gastropods (Britton \& Morton, 1993), the example of a muricid scavenger dominating the clean shallow subtidal environment of the reserve is of especial interest. The principal aim of this study was thus to examine the significance of Ergalatax contractus in the subtidal habitat of Lobster Bay. Accordingly, field studies were complemented by laboratory experiments concerned with various aspects of the feeding behaviour of E. contractus, including chemo-detection abilities in still and running water and feeding time. In sharing the same pool of potential nutrients with sympatric nassariids, however, it is possible that interspecific competition takes place between $E$. contractus and them. To examine this hypothesis, Nassarius nodifer Stimpson, 1858, with a shell height similar to that of E. contractus, was chosen for a general comparison of these representatives of the two families in terms of their feeding behaviours. Finally, manipulation experiments were performed to investigate any such possible interspecific interactions by modifying the ratio of the two species during collective feeding bouts.

\section{MATERIALS AND METHODS}

\section{Field experiments}

Following the design and protocol of Morton \& Chan (2000, figure 1, p. 259), traps baited with $20 \mathrm{~g}$ fish (Engraulidae: Stolephorus heterolobus) were used in an initial field experiment conducted in the summer of 2002 to collect Ergalatax contractus and other subtidal $(-3 \mathrm{~m}$ chart datum) scavengers from Lobster Bay and to determine their incidences. Modified designs of the traps have been used to study other components of the scavenging hyperbenthos of Lobster Bay (Lee, 2004, figure 3; Lee \& Morton, 2004, 2005). Scavengers attracted to the traps were identified upon retrieval after $2 \mathrm{~h}$ deployment and returned to the laboratory. Before being transferred to aquaria where they were kept for subsequent laboratory experiments, trapped gastropod species were counted and shell heights measured to the nearest $1 \mathrm{~mm}$. This experiment was repeated seven times.

In a second field experiment, fish bait $(20 \mathrm{~g})$ was placed in four of the five components of each of seven sets of traps and deployed for $7 \mathrm{~h}$. Empty trap components served as controls. One set of traps was removed from the sea after 1, 2, 3, 4, 5, 6 and $7 \mathrm{~h}$ and the numbers of Ergalatax contractus and other species of gastropod in each one recorded. This experiment was repeated three times.

\section{Laboratory experiments}

Except for Ergalatax contractus and Nassarius nodifer, all other species caught in the traps were returned to Lobster Bay after being identified and measured. Individuals of the 
Table 1. Numbers of Ergalatax contractus and Nassarius nodifer individuals retrieved from the traps (three trials) deployed in Lobster Bay, Cape d'Aguilar Marine Reserve after different deployment times and with totals and averages.

\begin{tabular}{|c|c|c|c|c|c|c|c|c|}
\hline \multirow[b]{2}{*}{$\begin{array}{l}\text { Time } \\
\text { (hours) }\end{array}$} & \multicolumn{2}{|c|}{ Trial 1} & \multicolumn{2}{|c|}{ Trial 2} & \multicolumn{2}{|c|}{ Trial 3} & \multicolumn{2}{|c|}{ Total numbers } \\
\hline & $\begin{array}{l}\text { Ergalatax } \\
\text { contractus }\end{array}$ & $\begin{array}{c}\text { Nassarius } \\
\text { nodifer }\end{array}$ & $\begin{array}{l}\text { Ergalatax } \\
\text { contractus }\end{array}$ & $\begin{array}{c}\text { Nassarius } \\
\text { nodifer }\end{array}$ & $\begin{array}{l}\text { Ergalatax } \\
\text { contractus }\end{array}$ & $\begin{array}{c}\text { Nassarius } \\
\text { nodifer }\end{array}$ & $\begin{array}{l}\text { Ergalatax } \\
\text { contractus }\end{array}$ & $\begin{array}{c}\text { Nassarius } \\
\text { nodifer }\end{array}$ \\
\hline 1 & 0 & 0 & 1 & 0 & 8 & 0 & 9 & 0 \\
\hline 2 & 5 & 1 & 6 & 1 & 23 & 0 & 34 & 2 \\
\hline 3 & 25 & 1 & 2 & 0 & 2 & 0 & 29 & 1 \\
\hline 4 & 67 & 0 & 50 & 0 & 41 & 0 & 158 & 0 \\
\hline 5 & 71 & 1 & 7 & 0 & 15 & 0 & 93 & 1 \\
\hline 6 & 4 & 1 & 43 & 0 & 11 & 0 & 58 & 1 \\
\hline 7 & 39 & 3 & 6 & 0 & 28 & 0 & 73 & 3 \\
\hline Totals & 211 & 7 & 115 & 1 & 128 & 0 & 454 & 8 \\
\hline Mean & 30.1 & 1.0 & 16.4 & 0.1 & 18.3 & 0 & 64.8 & 1.1 \\
\hline
\end{tabular}

two species of interest were identified by gluing numbered tags onto their dorsal shell surfaces and kept in separate aquaria with beds of sand and supplied with ambient seawater from Lobster Bay. Generally, the collected animals were deprived of food but hunger levels were standardized for all laboratory experiments by feeding them one week (sometimes two weeks, as will be described) prior to experimentation. All aquaria were cleaned thoroughly between experiments.

Ergalatas contractus: feeding times. In the first experiment, times spent feeding by Ergalatax contractus were investigated by placing fish food $(5 \mathrm{~g})$ and one individual $(\mathrm{N}=60)$ into a $1-1$ aquarium filled with ambient seawater. Times at which each individual commenced and finished feeding were recorded. Second and third feeding events were also recorded and, in these cases, the total time spent feeding was taken as the sum of all events. This experiment was repeated ten times for $E$. contractus individuals of three shell height ranges (10-15, 15-20, > $20 \mathrm{~mm})$, after both one and two weeks' starvation.

Ergalatax contractus: food detection distance in still and flowing water. In a second experiment, a long $(100 \mathrm{~cm})$ aquarium tank was used to investigate the effective chemo-detection distance of Ergalatax contractus in still water. Forty individuals of 15-20 mm shell height were starved for one week prior to experimentation, divided into four subsets of ten and lined up at distances of 50,60, 70 and $80 \mathrm{~cm}$ from $20 \mathrm{~g}$ fish bait located behind a screen at one end of the aquarium. The aquarium was filled with ambient seawater and the screen removed at time zero to allow for diffusion of bait 'odours'. The numbers of individuals arriving at the bait and the times taken for them to do so were recorded in relation to their initial distances from the food. This experiment was repeated three times. The same experiment was conducted again, but allowing unidirectional flow $\left(11 \mathrm{~min}^{-1}\right)$ from the bait towards the animals commencing at time zero.

Ergalatax contractus: the effect of starvation period and distance from provided bait. In a third experiment, the above long tank was employed again to examine the effects of starvation period and distance from the provided bait on the
Table 2. Percentage numbers of Ergalatax contractus of different shell height ranges and starvation periods that commenced feeding in the flowing water experiment. Average times (minutes) spent feeding are shown in parentheses. Significant differences $(\mathrm{P}=0.05)$ between different starvation periods are indicated by an asterisk.

\begin{tabular}{lcccc}
\hline $\begin{array}{l}\text { Starvation } \\
\text { period }\end{array}$ & $10-15 \mathrm{~mm}$ & $15-20 \mathrm{~mm}$ & $>20 \mathrm{~mm}$ & Average \\
\hline One week & $80 \%$ & $100 \%$ & $80 \%$ & $86.7 \%$ \\
& $(75.6)$ & $(82.7)$ & $(70.7)$ & $(78.0 *)$ \\
Two weeks & $90 \%$ & $60 \%$ & $100 \%$ & $83.3 \%$ \\
& $(50.8$ & $(50.8)$ & $(83.9)$ & $(62.8 *)$ \\
Average & $85 \%$ & $80 \%$ & $90 \%$ & $85.0 \%$ \\
& $(63.5)$ & $(67.8)$ & $(79.7)$ & $(70.6)$ \\
\hline
\end{tabular}

numbers of Ergalatax contractus arrivals at the bait in flowing water. As before, 40 individuals (shell heights $=15-20 \mathrm{~mm}$ ) that had been starved for one week were divided into four subsets of ten and lined up at distances of 50, 60, 70 and $80 \mathrm{~cm}$ from the bait $(20 \mathrm{~g})$ located behind the screen at the end of the tank. Numbers of individuals arriving at the bait and the times taken for them to do so were recorded in relation to their initial distances from the food. This experiment was repeated three times. The same experimental set-up was used on individuals starved for two weeks.

Nassarius nodifer: behaviour in comparison with Ergalatax contractus in still and flowing water. In a fourth experiment, the effective chemo-detection distance and feeding time of Nassarius nodifer were investigated in still and flowing water using the same protocol described above for Ergalatax contractus. Such experiments were, however, limited by the fewer individuals available for study. For each trial, five individuals, ranging in shell height from $12-24 \mathrm{~mm}$, were starved for one week prior to experimentation. The experiments were repeated three times with different individuals. The numbers of individuals arriving at the bait from different distances, the times taken for them to do so and feeding times were recorded and used to compare with 

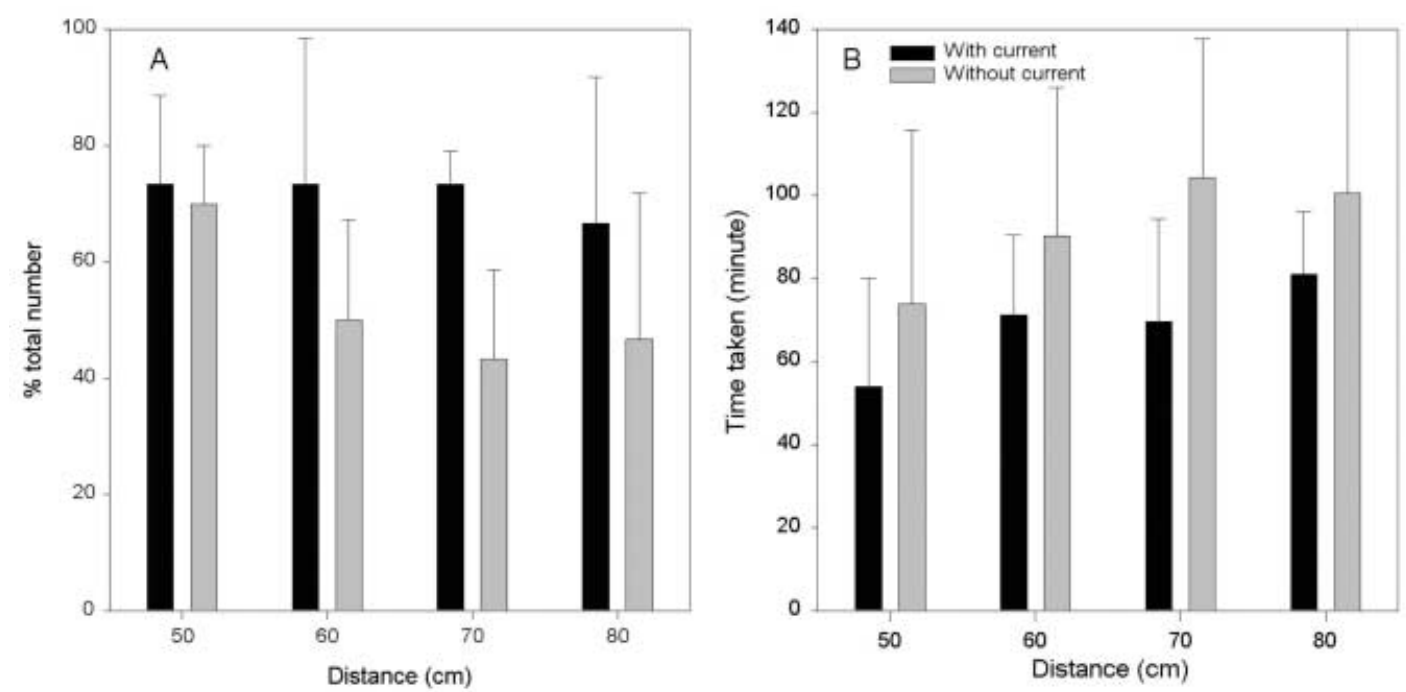

Figure 1. (A) The mean percentage numbers of arrivals and (B) mean arrival times at bait for Ergalatax contractus under conditions of still and flowing water. Vertical bars indicate standard deviations.
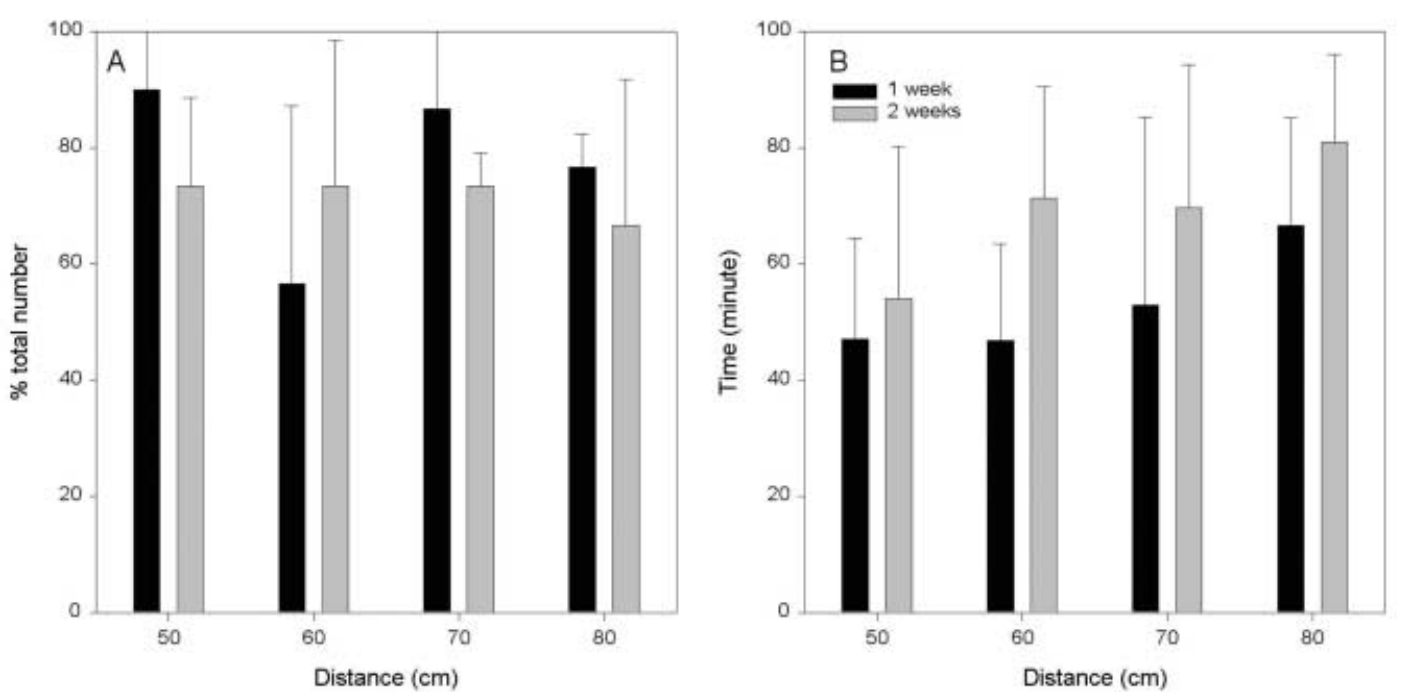

Figure 2. (A) The mean percentage numbers of arrivals and (B) mean arrival times at bait for Ergalatax contractus individuals experiencing one and two weeks' starvation. Vertical bars indicate standard deviations.

the behaviour of $E$. contractus (shell heights $=15-20 \mathrm{~mm}$ ) examined in Experiment 2.

Interactions between Ergalatax contractus and Nassarius nodifer. In a fifth experiment, Ergalatax contractus (shell height $=15-20 \mathrm{~mm}$ ) and Nassarius nodifer (shell height $=12-24 \mathrm{~mm}$ ) were allowed to feed together in plastic trays in ratios of 2:8, 5:5 and 8:2. All individuals were starved for one week. Ten individuals of the two species in the above ratios were lined up $15 \mathrm{~cm}$ away from fish bait $(10 \mathrm{~g})$. Directional water flow at a rate of $5 \mathrm{~cm} \mathrm{~s}^{-1}$ was provided from the carrion towards the animals. Times taken to arrive at the bait and finish feeding were recorded. Where necessary, total feeding times were calculated as the sum of all feeding bouts. The experiment was repeated three times for each ratio.
Statistical analyses. The statistical analyses described herein were undertaken using SAS 9.0. As the data obtained in the different laboratory experiments complied with normal distributions in the Shapiro-Wilk's test $(P S>0.05)$ with the same variances as in the Bartlett's test $(P S>0.05)$, the experimental results were examined using a two-way analysis of variance (ANOVA) (except for Experiment 4) without transformation to determine:

Experiment 1 -the effects of starvation period on the time spent feeding by Ergalatax contractus.

Experiment 2-the effects of distance from the bait in still and flowing water on the numbers of individuals of Ergalatax contractus arriving at the bait and the times taken for them to do so. The numbers and times taken to arrive at the bait by individuals making up the three sizecategories of E. contractus were further examined using a 

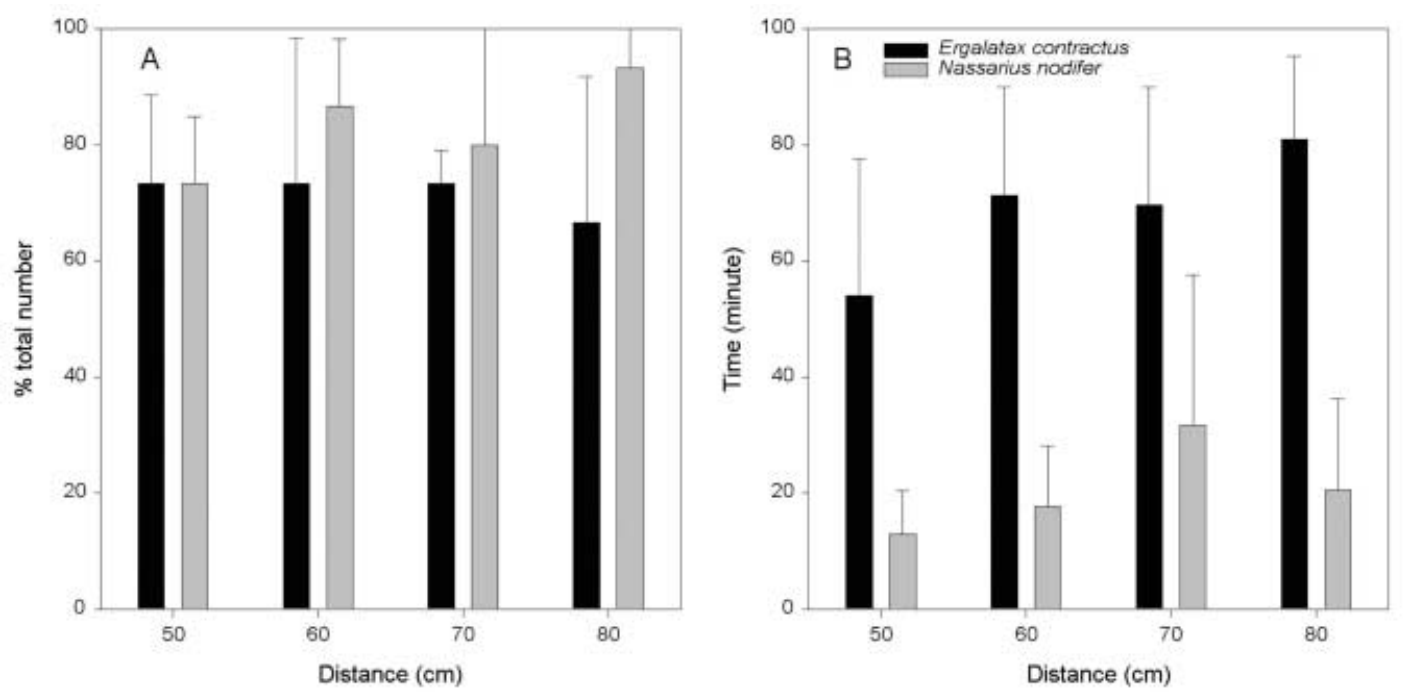

Figure 3. (A) Mean percentage numbers of arrivals and (B) mean arrival times at bait for Ergalatax contractus and $\mathcal{N}$ assarius nodifer in flowing water. Vertical bars indicate standard deviations.

$\chi^{2}$-test, $\mathrm{df}=2, \quad P>0.05$ and a Mann-Whitney test, $P \geqslant 0.05$, respectively.

Experiment 3-the effects of starvation period and distance from the provided bait on the numbers of individuals of Ergalatax contractus arriving to feed.

Experiment 4-if the data obtained on the effects of distance from the provided bait were different for Ergalatax contractus and $\mathcal{N}$. nodifer. A two-way (nested design) ANOVA was, however, used in this comparison.

Experiment 5-if the feeding behaviours' of Ergalatax contractus and Nassarius nodifer were different at numerically various ratios.

\section{RESULTS}

\section{Field experiments}

The total numbers of individuals of different species of gastropods attracted to the traps during the seven trials of the first field experiment were, in descending order of importance: Ergalatax contractus (238 [87.5\%]), Nassarius nodifer (17 [6.3\%]), Nassarius reeveanus (Powys, 1835) (5 $[1.8 \%])$, Thais clavigera (Küster, 1860) (5 [1.8\%]), Nassarius pauperus (Gould, 1850) (3 [1.1\%]) Mitrella bicincta (Gould, 1860) (3 [1.1\%]) and Thais luteostoma (Holten, 1803) (1 $[0.4 \%])$. The mean shell heights of $E$. contractus and $\mathcal{N}$. nodifer individuals collected in this experiment were $11.7 \pm 4.7 \mathrm{~mm}$ (range $3-32 \mathrm{~mm}$ ) and $21.8 \pm 4.8 \mathrm{~mm}$ (range $11-27 \mathrm{~mm})$, respectively.

The numbers of Ergalatax contractus and Nassarius nodifer attracted to the traps in the individual trials (and the totals) after different times in the second field experiment are given in Table 1 . The total numbers of $E$. contractus arriving at the baited traps increased slightly with time for the first $3 \mathrm{~h}$ and reached a peak after four, with a total of 158 individuals recovered. Thereafter, numbers of arrivals declined as individuals departed the traps, that is, the cumulative number of individuals was 93 after $5 \mathrm{~h}$, and this decreased to 58 and 73 after 6 and $7 \mathrm{~h}$, respectively. Nassarius nodifer arrived at the carrion in much lower numbers than $E$. contractus, as in the first experiment.

\section{Laboratory experiments}

Ergalatax contractus: feeding times. Feeding times of Ergalatax contractus after one and two weeks' starvation were examined in Experiment 1. Results for individuals with different shell height ranges are shown in Table 2. On average, $85.0 \%$ of individuals fed for $70.6 \mathrm{~min}$ when presented with food after both one and two week starvation periods. The percentage of feeding events was always $>80 \%$, regardless of shell height and starvation period experienced. Larger individuals of $E$. contractus generally spent a longer time feeding, that is, individuals of $>20 \mathrm{~mm}$ shell height spent a mean of $79.7 \mathrm{~min}$ on one single feeding event compared with those of between 10-15 mm shell height (a mean of $63.5 \mathrm{~min}$ ). No significant difference was detected, however, with regard to variations in size of $E$. contractus and times spent feeding $(P=0.189)$. Starvation period prior to experimentation significantly affected feeding time $(P=0.045)$ but there was, again, no significant interaction between this and size $(P=0.278)$.

Ergalatax contractus: behaviours in still and flowing water. The effects of static and flowing water on the chemodetection ability of Ergalatax contractus (Experiment 2) were examined and the results are illustrated in Figure 1. The percentage numbers of arrivals of E. contractus were significantly different in static and flowing water (Figure 1A) $(P=0.015)$. The average percentage numbers of arrivals was $52.5 \%$ with no flow, but this increased to $71.7 \%$ with flow. Although the percentage numbers of arrivals decreased with distance in both experimental groups, less than $50 \%$ of individuals were capable of reaching the bait from more than $60 \mathrm{~cm}$ away when there was no flow. Nevertheless, there was no significant difference in the percentage numbers of arrivals at the bait at different distances from the bait $(P=0.524)$. No interaction between the two factors was obtained $(P=0.015)$. The times taken for $E$. contractus to arrive at the bait were significantly different in static and flowing water (Figure 1B) $(P=0.034)$. The average time taken for $E$. contractus to arrive at the bait was $92.3 \mathrm{~min}$ in the absence of a unidirectional flow, 
Table 3. The times spent ( $A)$, locating food and ( $B)$, feeding by Nassarius nodifer and Ergalatax contractus when present in different ratios. Significant differences between times spent feeding are indicated by an asterisk. (C) Percentages of Nassarius nodifer and Ergalatax contractus that fed when present in different ratios.

\begin{tabular}{ccccc}
\hline & \multicolumn{3}{c}{ Ratio } & \\
\cline { 2 - 4 } Species & $8: 2$ & $5: 5$ & $2: 8$ & Average \\
\hline (A) Nassarius nodifer & 11.8 & 15.0 & 5.8 & $10.8 \mathrm{~min}$ \\
$\quad$ Ergalatax contractus & 23.5 & 31.9 & 28.7 & $28.1 \mathrm{~min}$ \\
(B) Nassarius nodifer & 29.5 & 28.4 & 22.8 & $27.4 \mathrm{~min}$ \\
$\quad$ Ergalatax contractus** & 42.0 & 98.9 & 70.1 & $70.3 \mathrm{~min}$ \\
(C) Nassarius nodifer & $87.5 \%$ & $80.0 \%$ & $100 \%$ & $89.1 \%$ \\
$\quad$ Ergalatax contractus & $83.3 \%$ & $93.3 \%$ & $91.7 \%$ & $89.4 \%$ \\
\hline & & & & \\
\hline
\end{tabular}

that is, one-third longer than that of 69.0 min with flow. More time was needed to arrive at the bait when distance from it was increased. There were not, however, significant differences in the times taken to arrive at the bait at different distances from it $(P=0.223)$. In addition, no interaction between the two parameters was obtained $(P=0.762)$. Finally, there was no significant difference in the numbers of individuals of different size-categories arriving at the bait $\left(\chi^{2}\right.$-test, $\left.\mathrm{df}=2, P>0.05\right)$ nor in the time taken for them to do so (Mann-Whitney test, $P>0.05$ ).

Ergalatax contractus: the effect of starvation period and distance from provided bait. The effects of starvation on Ergalatax contractus were also studied in Experiment 3 by comparing the percentage numbers of arrivals and the times taken to arrive at the bait from different distances in flowing water. The results are shown in Figure 2. There was no significant difference in the percentage numbers of arrivals of E. contractus experiencing different starvation periods (Figure 2A) $(P=0.456)$, that is, $71.7 \%$ and $77.5 \%$ after one and two weeks' starvation, respectively. There was a minor decrease in the percentage numbers of arrivals, although no significant difference was identified for different distances from the bait $(P=0.464)$. Finally, no interaction between the two parameters was detected $(P=0.425)$.

The times taken for Ergalatax contractus to arrive at the bait were significantly different for different starvation times (Figure 2B) $(P=0.018)$. Individuals experiencing starvation for one week took longer $(\sim 69.0 \mathrm{~min})$ to arrive at the bait than those starved for two weeks ( $\sim 53.4 \mathrm{~min})$. Yet, there was no significant difference in the times taken to arrive at the bait for different distances $(P=0.247)$. Similarly, no significant interaction between the two parameters was obtained $(P=0.746)$.

Nassarius nodifer: behaviour in still and flowing water and a comparison with Ergalatax contractus. In a fourth experiment, the behaviour of Nassarius nodifer was examined in still and flowing water and comparisons made with Ergalatax contractus. The average time taken for all (100\%) $\mathcal{N}$. nodifer individuals to arrive at the bait in still water was $30.2 \mathrm{~min}$, that is, significantly $(P=0.048)$ one-third longer

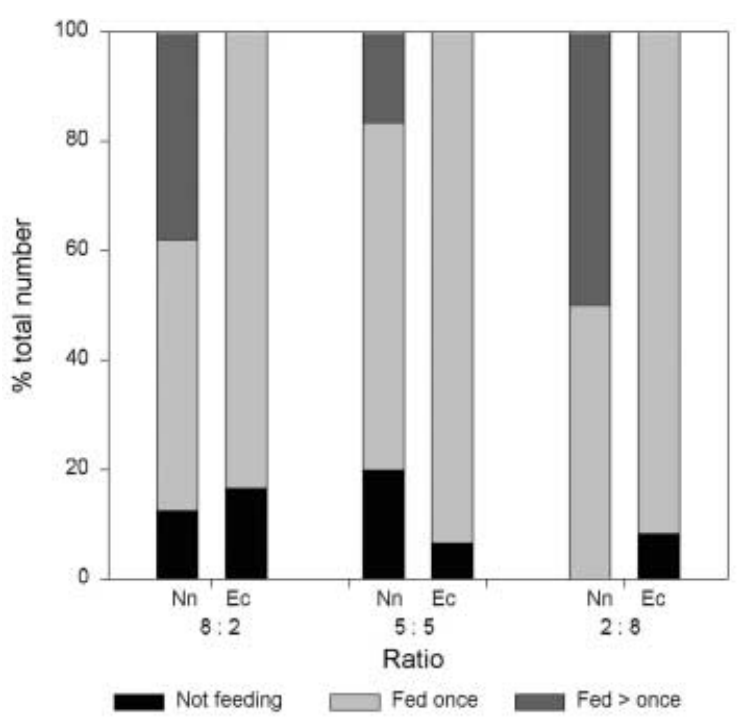

Figure 4. The percentage numbers of Ergalatax contractus and $\mathcal{N}$ assarius nodifer undertaking feeding bouts when interacting in ratios of $8: 2,5: 5$ and $2: 8$.

than the $20.8 \mathrm{~min}$ (also $100 \%$ of individuals) with flow. Under conditions of flowing water, there was no significant difference in the percentage numbers of arrivals of $E$. contractus and $\mathcal{N}$. nodifer at the bait $(P=0.083)$, that is, averages of $71.7 \%$ and $83.3 \%$, respectively (Figure 3 ). The percentage numbers of arrivals of $\mathcal{N}$. nodifer did not show a specific trend, but those of E. contractus decreased slightly with an increase in distance between the individuals and the bait (Figure 3A). There was also no significant difference in the percentage numbers of arrivals placed at different distances from the bait $(P=0.788)$. The distances at which individuals were placed from the food also did not show a significant interaction for either of the two species $(P=0.585)$. There was a significant difference $(P=0.032)$ in the mean times feeding by $\mathcal{N}$. nodifer (25.7 $\mathrm{min})$ and $E$. contractus (70.6 $\mathrm{min}$ ) in flowing water.

The times taken to arrive at the bait were highly significantly different for Ergalatax contractus and Nassarius nodifer (Figure 3B) $(P \leqslant 0.000)$, despite the high percentage numbers of arrivals by the former. Nassarius nodifer generally took an average of $20.8 \mathrm{~min}$ to travel to the bait whereas E. contractus took $69.0 \mathrm{~min}$. No significant differences in the times taken to arrive at the bait were identified at different distances $(P=0.182)$. The interaction effect between the two parameters was also statistically insignificant $(P=0.965)$.

Interactions between Ergalatax contractus and Nassarius nodifer. The effects of changing the ratios of Ergalatax contractus and Nassarius nodifer were examined in Experiment 5 (Table 3 \& Figure 4). The percentage of individuals involved in feeding was high $(>80 \%)$ for both species, with no significant difference among the three ratios $(P=0.345)$. Nor was there a significant difference in the time required to locate the bait $(P=0.440)$ when the two species were present in different ratios. Nassarius nodifer did not demonstrate a significant variation in the time spent feeding $(P=0.921)$ for the three ratios, but $E$. contractus showed a significant increase $(P=0.038)$. 
Table 4. A summary comparison of the feeding strategies adopted by Ergalatax contractus and Nassarius nodifer towards carrion.

\begin{tabular}{lcc}
\hline Character & $\begin{array}{c}\text { Ergalatax } \\
\text { contractus }\end{array}$ & $\begin{array}{c}\text { Nassarius } \\
\text { nodifer }\end{array}$ \\
\hline $\begin{array}{l}\text { Mean numbers of arrivals in still } \\
\quad \text { water (\%) }\end{array}$ & 52.5 & 100 \\
$\begin{array}{l}\text { Mean numbers of arrivals in moving } \\
\quad \text { water (\%) }\end{array}$ & 71.0 & 83.3 \\
$\begin{array}{l}\text { Mean time taken to arrive at food } \\
\quad \text { (no flow) (minutes) }\end{array}$ & 92.3 & 30.2 \\
$\begin{array}{l}\text { Mean time taken to arrive at food } \\
\quad \text { (with flow) (minutes) }\end{array}$ & 69.0 & 20.8 \\
$\begin{array}{l}\text { Mean time taken to consume one } \\
\text { meal (minutes) }\end{array}$ & 70.6 & 25.7 \\
$\begin{array}{l}\text { Mean time to find food when } \\
\text { interacting (minutes) }\end{array}$ & 28.1 & 10.8 \\
$\begin{array}{l}\text { Mean time to consume one meal } \\
\quad \text { when interacting (minutes) }\end{array}$ & 70.3 & 27.4 \\
$\begin{array}{l}\text { Leaves food after feeding? } \\
\text { P. }\end{array}$ & No & Yes \\
\hline
\end{tabular}

Nonetheless, the experimental results confirm that Nassarius nodifer required less time $(\sim 10.8 \mathrm{~min})$ to locate the food as compared with Ergalatax contractus ( $28.0 \mathrm{~min})$. Nassarius nodifer also spent less time ( $\sim 27.4 \mathrm{~min})$ feeding on the carrion than $E$. contractus ( $\sim 70.3 \mathrm{~min})$.

Behavioural differences between the two species lay not only in the speed at which they arrived at and consumed the bait, but also the number of returns in a single feeding episode (Figure 4). No Ergalatax contractus fed twice, that is, all individuals feed to satiation and usually remained close to the bait. About $35 \%$ of Nassarius nodifer returned once to the bait, however, some even engaging in a third feeding bout over the experimental period. Eventually, however, all departed it. Such behaviour has been observed in other nassariids, such as Nassarius festivus (Morton, 1990) and Nassarius mendicus (Britton \& Morton, 1993).

\section{DISCUSSION}

The diverse species of the Muricidae are predators that are believed responsible for regulating prey populations on the rocky shores they mainly inhabit worldwide (Navarette, 1996; Navarette \& Menge, 1996; Taylor \& Morton, 1996). In contrast, the equally diverse Nassariidae has scavenging representatives that are important in the removal of carrion from the marine benthic environment (Britton \& Morton, 1993, 1994b). Regardless of the above generalizations, Ergalatax contractus occupies the niche of a scavenger and shares carrion with several nassariids in the subtidal sands of Lobster Bay, Cape d'Aguilar Marine Reserve and elsewhere in Hong Kong. In a number of field trials (Morton \& Chan, 2000; this study), E. contractus was captured using carrion-baited traps in large numbers along with other scavenging species, including Nassarius pauperus, Nassarius reeveanus and Nassarius nodifer. The great difference between the numbers of E. contractus ( $>88 \%$ ) and all other scavenging species attracted to baited traps indicates that not only is it abundant, but it readily recognized carrion as food, as previously noted by Morton \& Chan (2000).
Table 4 compares the feeding characteristics of Ergalatax contractus and Nassarius nodifer, as determined in this study. The percentages of laboratory feeding events were high for E. contractus regardless of starvation period, that is, an average of $85 \%$ of individuals each spent $\sim 70.6 \mathrm{~min}$ consuming the food provided. Nassarius nodifer spent but 25.7 min feeding. According to Britton \& Morton (1994b), feeding quickly is a characteristic of scavenging nassariids, the duration of which is affected by the interval between feeding events. Buccinids, including Buccinum undatum (Himmelman, 1988), spend a longer time feeding and duration varies little, for example, Cominella eburnea on south-west Australian beaches (Britton \& Morton, 1993).

Ergalatax contractus spent a shorter time feeding after a longer period of starvation. That is, it eats faster to satiation as a homeostatic response to starvation, so that its energy balance can be restored quickly (Hughes, 1986; Morton, 1990; Cheung, 1994). This is an essential adaptation for adoption of a scavenging mode of life with an infrequent supply of carrion (Britton \& Morton, 1994b). An immediate rise in metabolic rate inferred from higher oxygen up-take levels has been reported upon for Nassarius festivus (Cheung, 1994) and Nassarius reticulatus (Crisp et al., 1978) as appetitive behaviour. This physiological response allows the scavenger to search for and arrive at food quickly, thereby increasing its chance of gaining sufficient nutrition to sustain a positive energy balance (Britton \& Morton, 1994a,b).

Comparing species' responses towards food odours with and without flowing water is important in determining the significance of currents (Nickell \& Moore, 1992b). There are, however, few behavioural studies on the responses of benthic animals in still water, or field studies. The abilities of a suite of carrion feeding nassariids and buccinids to detect and respond to odours from fish-baited traps in Princess Royal Harbour, Western Australia, declined with time of bait immersion, probably as the amounts of blood emanating from it also declined (Morton \& Jones, 2003). The ability of Ergalatax contractus to detect potential food was low in the absence of directional flow. Coupled with a significant decrease in the percentage number of E. contractus arrivals, the time taken to reach bait also increased significantly. Nassarius nodifer on the other hand did not show a decreasing trend in terms of the percentage number of arrivals when the distance to bait was increased, although the time needed to do so increased slightly. The percentage number of arrivals remained high $(>70 \%)$ for all distances and $\mathcal{N}$. nodifer always arrived fast, indicating acute chemoreception and rapid mobility.

With no similar studies on species of Muricidae it is difficult to make many generalizations, but much research has been done on the Nassariidae. The Californian subtidal scavengers Nassarius mendicus and Nassarius perpinguis can only detect carrion from $<10 \mathrm{~cm}$ and $<2.5 \mathrm{~cm}$, respectively (Britton \& Morton, 1994a). The detection distance of the similarly subtidal Nassarius siquijorensis in Hong Kong is longer, at $35 \mathrm{~cm}$ (Liu \& Morton, 1994a). Nassarius pyrrhus and Nassarius festivus in the intertidal zone are more sensitive and are capable of moving towards carrion bait from distances of $1 \mathrm{~m}$ and $2.5 \mathrm{~m}$, respectively (Morton \& Britton, 1991; Morton \& Yuen, 2000). On shores experiencing large tidal ranges, however, such as in northern Western Australia, Nassarius 
clarus and Nassarius dorsatus can detect carrion from distances > $200 \mathrm{~m}$ (Morton, 2003; Morton \& Britton, 2003). The movement of nassariid scavengers is generally fast, enabling them to better exploit carrion in the sea. For example, $\mathcal{N}$. festivus took $<45 \mathrm{~min}$ to reach food placed $1 \mathrm{~m}$ away (Britton \& Morton, 1993). Nassarius pyrrhus, on the other hand, found carrion from a distance of $20 \mathrm{~cm}$ in 9 min (Morton \& Britton, 1991). As demonstrated herein, Nassarius nodifer located carrion $15 \mathrm{~cm}$ away in $\sim 10 \mathrm{~min}$. Fast movement, however, implies a greater energetic cost (Hughes, 1986). Nassarius nodifer also spent only brief periods of $\sim 27.4 \mathrm{~min}$ feeding (when interacting with $E$. contractus) and if it consumed large amounts of food during this time, then it is behaving like a typical member of the Nassariidae. For example, the intertidal $\mathcal{N}$. festivus consumed $>50 \%$ of its body weight in an average feeding bout of $\sim 13$ min (Morton, 1990; Cheung, 1994). Its Hong Kong subtidal counterpart, Nassarius siquijorensis, consumed $60 \%$ of its body weight in a single feeding bout of $\sim 20 \mathrm{~min}$ (Liu \& Morton, 1994a).

The availability of carrion in the sea is scarce and generally not constant, with the exception of fishery discards (Britton \& Morton, 1993, 1994b). Inter- and intraspecific interactions, most probably in the form of competition and predation, disturb the feeding activities of scavengers (Morton \& Britton, 1991; Morton \& Yuen, 2000). There are also complications arising from variations in the population densities and relative speeds of scavenging species (Nickell \& Moore, 1992a). All such factors act as selective forces through differential resource allocation within a scavenging community (Morton \& Britton, 1991).

Effects of competition are difficult to demonstrate in the field because of the complexity of the interacting ecosystem, for example, microhabitat variability, activity patterns and dietary preferences (Schoener, 1974; Kent, 1983). As suggested by Morton \& Yuen (2000), the most common method of demonstrating interspecific interactions is by manipulating the relative abundances of sympatric species and observing changes in behaviour (Connell, 1961). The percentages of Ergalatax contractus and Nassarius nodifer feeding on carrion were both high in the interaction experiments. A decrease in time needed for location and consumption of carrion was observed, although not significantly so, for $\mathcal{N}$. nodifer when its relative numbers were decreased experimentally. Ergalatax contractus did, however, show a significant decrease in feeding time with a decline in its relative numbers, thereby demonstrating that this activity is susceptible to disturbance by other scavengers in proximity to it, in this case $\mathcal{N}$. nodifer. This is probably the same in the subtidal environment of Lobster Bay where the field experiments showed that more than one scavenger species competes for limited carrion resources.

Ergalatax contractus is generally considered to be a predator. Gut contents analysis revealed its diet to comprise polychaetes but also crustacean and gastropod fragments and detritus, that is, carrion (Taylor \& Morton, 1996). In other studies, barnacles, oysters and mussels are also included in its diet (Ishida, 2001). Although E. contractus was reported to feed on Hormomya mutabilis in Japan, it mostly engaged in scavenging other predators' leftovers, instead of drilling the prey itself
(Ishida, 2001, 2004). Scavenging was not, however, considered to be an important behaviour for $E$. contractus in Japan because carrion was not readily available to it. The situation is, however, different in Hong Kong. In local shallow waters, carrion is largely the by-product of human activities. All Hong Kong's seabed is affected by either direct or indirect perturbations through pollution, trawling and dredging which supply an enhanced food resource not normally available to scavengers (Britton \& Morton, 1994b). With the use of environmentally damaging fishing techniques, subtidal environments suffer from constant and direct disturbance by bottom trawlers (Taylor, 1994; Leung \& Morton, 1997, 2000, 2003). This fishing technique has severe impacts on the local benthic fauna, causing periodic exposure, injury and mortality (Taylor, 1994; Morton, 1996).

The impacts exerted by the addition of allochthonous carrion to the marine environment vary to different extents, and are affected by the amount and frequency, as well as its relative importance when compared to the natural abundance of other food sources (Ramsay et al., 1997). Given that scavengers are favoured strongly by perturbation, it is understandable that they have proliferated in recent years as a result of enhanced bottom disturbance (Taylor, 1994; Britton \& Morton, 1994b; Morton, 1995). In Hong Kong, with the increase in marine environmental perturbation, a decrease in species richness and abundance has been documented in which generalists, especially scavengers, have replaced specialized predators (Taylor \& Shin, 1990; Britton \& Morton, 1994b; Taylor, 1994; Morton, 1995, 1996; Leung \& Morton, 1997, 2000, 2003). Ramsay et al. (1997) and Ramsay et al. (1998) have also demonstrated an increase in scavengers with an increase in fishery discards which provide a major and continuous source of carrion.

Britton \& Morton (1994b) suggested that carrion from natural sources is scarce in the marine environment as animals rarely die from senescence. Similarly, the leftovers from predation probably contribute little to the diets of scavengers, although Ruxton \& Houston (2004), while noting that a large marine scavenger has yet to be identified, consider, in theoretical terms, that such species could exist. Although autochthonous carrion may be of less significance to Hong Kong's marine environment, such a generalization may not apply so rigorously to the Cape d'Aguilar Marine Reserve. Large prey, especially that incompletely consumed, attracts other carnivorous or scavenging species to it and on the rocky shores of Cape d'Aguilar where rock surface temperatures soar to $50^{\circ} \mathrm{C}$ in summer, there is an annual kill of many species which thereby become available as carrion (Liu \& Morton, 1994b). Furthermore, chemicals released during prey consumption lead to aggregative feeding, where followers join in after the primary handling of the prey by the initial predator (Taylor \& Morton, 1996; Ishida, 2001). More than one individual of either one or more species constitute these feeding aggregations. The signals can either be the blood leaked from the prey (Ishida, 2001) or chemicals secreted by the predators themselves (Hughes, 1986), but the result is the same-other scavengers are attracted to either excess or leftover prey. Thais clavigera and Thais luteostoma were reported to feed collectively in large aggregations $(\mathrm{N}=33)$ on gastropods and bivalves in the 
Cape d'Aguilar Marine Reserve (Taylor, 1998). Drupella rugosa (Morton et al., 2002) and Rapana bezoar (Morton, 1994) similarly move towards prey attacked by conspecifics, creating feeding aggregations. Ergalatax contractus also participates in aggregative feeding on the subtidal sands of Lobster Bay and in tide pools in Wakayama, Japan (Taylor, 1980; Ishida, 2001).

Interspecific competition is common in the natural environment. The extent of competition varies with requirements and morphological similarities (Branch, 1984; Hughes, 1986). With near-identical requirements and morphologies, competition should be more intense for individuals of the same species than those of different ones. There are sufficient reasons to believe that Ergalatax contractus and Nassarius nodifer compete for the same limited resources as they are of similar sizes and have similar nutritional requirements in the same location. The availability of food in an undisturbed system decreases when more individuals participate in consumption (Hughes, 1986). Carrion supply has also been identified as one of the factors controlling population numbers and the structure of scavenging communities (Britton \& Morton, 1994b; Morton \& Chan, 2003), both in Hong Kong (Britton \& Morton 1994a) and southern Australia (McKillup \& Butler, 1983). Coupled with its infrequency and unpredictability, competition for the finite resource of carrion thus acts as a regulatory force in shaping community composition. According to the Gause principle, species cannot co-exist if their patterns of resource utilization are too similar (Schoener, 1974). Competition leads to elimination of the weaker species, but this is true only when resources are stable (Hughes, 1986). Interspecific competition may be less important between dominating species when compared with intraspecific competition as all the latter individuals share the same fundamental requirements and functional characteristics (Cheung, 1994).

Connell (1961) suggested that intraspecific competition is responsible for the uniform distribution of a species within its range. The range of a species was also shown to decrease in the presence of another having similar requirements. In spite of these generalizations, co-occurring species are suggested to behave differently in terms of resource utilization and, thereby, do not actually compete with each other. Competitive interspecific interactions have been identified for a muricid community in Japan (Ishida, 2001, 2004). Competition between Nassarius festivus and the hermit crab Diogenes edwardsii in Hong Kong has also been identified (Morton \& Yuen, 2000). Competitors do not only co-exist with each other, but also distribute themselves in different ways (Taylor, 1976, 1980; Morton \& Harper, 1997). Populations of nassariids, which are mostly scavengers, are also regulated by competition (Britton \& Morton, 1994b). Intraspecific competition has been identified for Nassarius festivus that aggregates around carrion in the field in such numbers that some individuals could not feed (Cheung, 1994). The subtidal Nassarius mendicus and Nassarius perpinguis co-exist and compete for carrion in Monterey Bay, California (Britton \& Morton, 1994a). Morton \& Britton (1991) demonstrated a similar partitioning between Nassarius pyrrhus (and other nassariids) and a bivalve predator, that is, Cominella eburnea (Buccinidae) on a sandy beach in
Western Australia. The relationship between $\mathcal{N}$. pyrrhus and C. eburnea is similar to that identified here between $\mathcal{N}$. nodifer and $E$. contractus. That is, the two nassariids arrived at bait first, ate rapidly and departed it. The slower buccinid and muricid arrived slowly, ate slowly and remained for longer with the food. Like C. eburnea, therefore, E. contractus is a predator with all the traits of such a lifestyle but also an opportunistic scavenger that has in the particular situation of carrion-rich Hong Kong become locally numerous and highly successful.

Carrion is rarely naturally available in the intertidal zone (Britton \& Morton, 1994b), so that here competition for this resource is intense. A food deficiency can lead to an increase in adult mortality (Hughes, 1986) and predation within the same species, that is, cannibalism. Nassarius festivus has been reported to perform post-larval shell drilling when food is lacking (Morton \& Chan, 1997). This behaviour increases the survival chance of juveniles, whereas adults usually conserve energy expenditure (Morton \& Chan, 1997). Thais orbita, a generalist predator on rocky shores in south-western Australia also cannibalizes juvenile conspecifics during food shortages (Morton \& Britton, 1993). Furthermore, other predatory species on the shore, such as Thais clavigera and Morula musiva (Tong, 1986; Taylor \& Morton, 1996), may limit the vertical distribution of Ergalatax contractus by preying upon it higher up. This might help explain the confinement of E. contractus to lower intertidal rocks and the subtidal sand patches of Lobster Bay. In such a situation and although here, as elsewhere (Britton \& Morton 1994b), fast moving, fast eating nassariids are the usual marine molluscan scavengers, the dominance of $E$. contractus in Lobster Bay and elsewhere in Hong Kong, is unusual. Here, the normally predatory $E$. contractus, far outnumbers all other scavengers, possibly because of an enhanced, largely allochthonous, supply of food which it is able to exploit by virtue of its previously identified opportunistic habit of scavenging the leftovers of other predators (Ishida, 2001, 2004).

I am grateful to Lora Lam and Paul Hodgson, The Swire Institute of Marine Science, The University of Hong Kong, for technical help and to Dr C.N.W. Lee, The Natural History Museum, London, for statistical advice.

\section{REFERENCES}

Bayliss, D.E., 1982. Switching by Lepsiella vinosa (Gastropoda) in South Australian mangroves. Oecologia, 54, 212-216.

Boss, K.J., 1982. Mollusca. In Synopsis and classification of living organisms (ed. S.B. Parker), pp. 947-1166. New York: McGrawHill Book Co.

Branch, G.M., 1984. Competition between marine organisms: ecological and evolutionary implications. Oceanography and Marine Biology. Annual Review, 22, 429-593.

Britton, J.C. \& Morton, B., 1992. The ecology and feeding behaviour of Nassarius festivus (Prosobranchia: Nassariidae) from two Hong Kong bays. In The marine flora and fauna of Hong Kong and Southern China III. Proceedings of the fourth international marine biological workshop: the marine flora and fauna of Hong Kong and Southern China, Hong Kong 1989 (ed. B. Morton), pp. 395-416. Hong Kong: Hong Kong University Press. 
Britton, J.C. \& Morton, B., 1993. Are there obligate marine scavengers? In The marine biology of the South China Sea. Proceedings of the first international conference on the marine biology of Hong Kong and the South China Sea, Hong Kong 1990 (ed. B. Morton), pp. 357-391. Hong Kong: Hong Kong University Press.

Britton, J.G. \& Morton, B., 1994a. Food choice, detection, time spent feeding, and consumption by two species of subtidal Nassariidae from Monterey Bay. California. Veliger, 37, 81-92.

Britton, J.C. \& Morton, B., 1994b. Marine carrion and scavengers. Oceanography and Marine Biology. Annual Review, 32, 369-434.

Carriker, M.R., 1981. Shell penetration and feeding by naticacean and muricacean predatory gastropods: a synthesis. Malacologica, 20, 403-422.

Chan, K. \& Morton, B., 2005. The reproductive biology of Nassarius festivus (Powys, 1835) (Gastropoda: Nassariidae) in relation to seasonal changes in temperature and salinity in subtropical Hong Kong. Aquatic Ecology, 39, 213-228.

Cheung, S.G., 1994. Feeding behaviour and activity of the scavenging gastropod Nassarius festivus (Powys). In The malacofauna of Hong Kong and Southern China III. Proceedings of the third international workshop on the malacofauna of Hong Kong and Southern China, Hong Kong 1992 (ed. B. Morton), pp. 327-338. Hong Kong: Hong Kong University Press.

Connell, J.H., 1961. The influence of interspecific competition and other factors on the distribution of the barnacle Chthamalus stellatus. Ecology, 42, 710-723.

Crisp, M., Davenport, J. \& Shumway, S.E., 1978. Effects of feeding and of chemical stimulation on the oxygen uptake of Nassarius reticulatus (Gastropoda: Prosobranchia). Fournal of the Marine Biological Association of the United Kingdom, 58, 387-399.

Harper, E. \& Morton, B., 1997. Muricid predation upon an under-boulder community of epibassate bivalves in the Cape d'Aguilar Marine Reserve, Hong Kong. In The marine flora and fauna of Hong Kong and Southern China IV. Proceedings of the eighth international marine biological workshop: the marine flora and fauna of Hong Kong and Southern China, Hong Kong 1995 (ed. B. Morton), pp. 263-284, Hong Kong: Hong Kong University Press.

Himmelman, J.H., 1988. Movements of whelks (Buccinum undatum) towards a baited trap. Marine Biology, 97, 521-531.

Hughes, R.N., 1986. A functional biology of marine gastropods. London: Croom Helm.

Ishida, S., 2001. Analysis of feeding aggregations in intertidal muricids: species-specific modes of foraging - initial predation and parasitism. Asian Marine Biology, 18, 1-13.

Ishida, S., 2004. Initial predation and parasitism by muricid whelks demonstrated by the correspondence between drilled holes and their apparent enveloper. Fournal of Experimental Marine Biology and Ecology, 305, 233-245.

Kent, B.W., 1983. Patterns of coexistence in busyconine whelks. Fournal of Experimental Marine Biology and Ecology, 66, 257-283.

Kohn, A.J., 1961. Chemoreception in gastropod mollusks. American Zoologist, 1, 291-308.

Lee, C.N.W., 2004. The distribution of necrophagous copepods in the Cape d'Aguilar Marine Reserve, Hong Kong. Zoological Studies, 43, 304-313.

Lee, G.N.W. \& Morton, B., 2004. Temporal patterns of change in the necrophogous hyperbenthic zooplankton community of Lobster Bay, Cape d'Aguilar Marine Reserve, Hong Kong. Fournal of the Marine Biological Association of the United Kingdom, 84, 531-538.

Lee, G.N.W. \& Morton, B., 2005. Demography of Nebalia sp. (Crustacea: Leptostraca) determined by carrion bait trapping in Lobster Bay, Cape d'Aguilar Marine Reserve, Hong Kong. Marine Biology, 148, 149-157.
Leung, K.F. \& Morton, B., 1997. The impacts of dredging on the epibenthic molluscan community of the southeastern waters of Hong Kong: a comparison of the 1992 and 1995 trawl programmes. In The marine flora and fauna of Hong Kong and Southern China IV. Proceedings of the eighth international marine biological workshop: the marine flora and fauna of Hong Kong and Southern China, Hong Kong 1995 (ed. B. Morton), pp. 401-436. Hong Kong: Hong Kong University Press.

Leung, K.F. \& Morton, B., 2000. The impacts of dredging and trawling on the epibenthic molluscan community of the southeastern waters of Hong Kong: a comparison of the 1992, 1995 and 1998 trawl programmes. In The marine flora and fauna of Hong Kong and Southern China V. Proceedings of the tenth international marine biological workshop: the marine flora and fauna of Hong Kong and Southern China, Hong Kong 1998 (ed. B. Morton), pp. 553-617. Hong Kong: Hong Kong University Press.

Leung, K.F. \& Morton, B., 2003. Effects of long-term anthropogenic perturbations on four subtidal epibenthic molluscan communities in Hong Kong. In Perspectives on marine nvironmental change in Hong Kong and Southern China 1977-2001 (ed. B. Morton), pp. 655-718. Hong Kong: Hong Kong University Press.

Liu J.H. \& Morton, B., 1994a. Food choice, detection, time spent feeding, consumption and effects of starvation on a subtidal scavenger, Nassarius siquijorensis (Gastropoda: Nassariidae), from Hong Kong. In The malacofauna of Hong Kong and Southern China III. Proceedings of the third international workshop on the malacofauna of Hong Kong and Southern China, Hong Kong 1992 (ed. B. Morton), pp. 357-375. Hong Kong: Hong Kong University Press.

Liu, J.H. \& Morton, B., 1994b. The temperature tolerances of Tetraclita squamosa (Crustacea: Cirripedia) and Septifer virgatus (Bivalva: Mytilidae) on a sub-tropical rocky shore in Hong Kong. Fournal of Zoology, 234, 325-339.

McKillup, S.C. \& Butler, A.J., 1983. The measurement of hunger as a relative estimate of food availability to populations of Nassarius pauperatus. Oecologia (Berlin), 56, 16-22.

Moran, M.J., Fairweather, P.G. \& Underwood, P.G., 1984. Growth and mortality of the predatory intertidal whelk Morula marginalba Blainville (Muricidae): the effects of different species of prey. Fournal of Experimental Marine Biology and Ecology, 75, 1-17.

Morton, B., 1990. The physiology and feeding behaviour of two marine scavenging gastropods in Hong Kong: the subtidal Babylonia lutosa (Lamarck) and the intertidal Nassarius festivus (Powys). Journal of Molluscan Studies, 56, 275-288.

Morton, B., 1994. Prey preferences and method of attack by Rapana bezoar (Gastropoda: Muricidae) from Hong Kong. In The malacofauna of Hong Kong and Southern China III. Proceedings of the third international workshop on the malacofauna of Hong Kong and Southern China, Hong Kong 1992 (ed. B. Morton), pp. 309-323. Hong Kong: Hong Kong University Press.

Morton, B., 1995. Perturbated soft intertidal and subtidal marine communities in Hong Kong: the significance of scavenging gastropods. In The marine biology of the South China Sea II. Proceedings of the second international conference on the marine biology of the South China Sea, Guangzhou, China 1993 (ed. B. Morton et al.), pp. 1-15. Beijing, China: World Publishing Corporation.

Morton, B., 1996. The subsidiary impacts of dredging (and trawling) on a subtidal benthic molluscan community in the southern waters of Hong Kong. Marine Pollution Bulletin, 32, 701-710.

Morton, B. 2003. Observations on the feeding behaviour of Nassarius clarus (Gastropoda: Nassariidae) in Shark Bay, Western Australia. Molluscan Research, 23, 239-249. 
Morton, B., Blackmore, G. \& Kwok, C.T., 2002. Corallivory by Drupella rugosa (Gastropoda: Muricidae) in Hong Kong. Journal of Molluscan Studies, 68, 217-223.

Morton, B. \& Britton, J.C., 1991. Resource partitioning strategies of two sympatric scavenging snails on a sandy beach in Western Australia. In Proceedings of the third international marine biological workshop: the marine flora and fauna of Albany, Western Australia 1988 (ed. F.E. Wells et al.), pp. 579-595. Perth: Western Australian Museum.

Morton, B. \& Britton, J.C., 1993. The ecology, diet and foraging strategy of Thais orbita (Neogastropoda: Muricidae) on a rocky shore of Rottnest Island, Western Australia. In Proceedings of the fifth international marine biological workshop: the marine flora and fauna of Rottnest Island, Western Australia (ed. F.E. Wells et al.), pp. 539-563. Perth: Western Australian Museum.

Morton, B. \& Britton, J.C., 2003. The behaviour and feeding ecology of a suite of gastropod scavengers at Watering Cove, Burrup Peninsula, Western Australia, Australia. In Proceedings of the eleventh international marine biological workshop: the marine flora and fauna of Dampier, Western Australia 2000 (ed. F.E. Wells et al.), pp. 147-171. Perth: Western Australian Museum.

Morton, B. \& Chan, K., 1997. The first report of shell-boring predation by a representative of the Nassariidae (Gastropoda). Fournal of Molluscan Studies, 63, 480-482.

Morton, B. \& Chan, K., 1999. Hunger rapidly overcomes the risk of predation in the subtidal scavenger Nassarius siquijorensis (Gastropoda: Nassariidae): an energy budget and a comparison with the intertidal Nassarius festivus. Fournal of Experimental Marine Biology and Ecology, 240, 213-228.

Morton, B. \& Chan, K., 2000. Scavenging behaviour of Nassarius pauperus (Gastropoda: Nassariidae) from the dynamic subtidal sands of Lobster Bay, Cape d'Aguilar Marine Reserve, Hong Kong. In The marine flora and fauna of Hong Kong and Southern China V. Proceedings of the tenth international marine biological workshop: the marine flora and fauna of Hong Kong and Southern China, Hong Kong 1998 (ed. B. Morton), pp. 255-266. Hong Kong: Hong Kong University Press.

Morton, B. \& Chan, K., 2003. The natural diet and degree of hunger of Nassarius festivus (Gastropoda: Nassariidae) on three beaches in Hong Kong. Fournal of Molluscan Studies, 69, 392-395.

Morton, B. \& Chan, K., 2004. The population dynamics of Nassarius festivus (Gastropoda: Nassariidae) on three environmentally different beaches in Hong Kong. Fournal of Molluscan Studies, 70, 329-339.

Morton, B. \& Harper, E., 1995. An introduction to the Cape d'Aguilar Marine Reserve, Hong Kong. Hong Kong: Hong Kong University Press.

Morton, B. \& Harper, E., 1997. An undescribed macrofaunal assemblage from shallow subtidal sands at the Cape d'Aguilar Marine Reserve, Hong Kong. In The marine flora and fauna of Hong Kong and Southern China IV. Proceedings of the eighth international marine biological workshop: the marine flora and fauna of Hong Kong and Southern China, Hong Kong 1995 (ed. B. Morton), pp. 249-261. Hong Kong: Hong Kong University Press.

Morton, B. \& Jones, D.S., 2003. The dietary preferences of a suite of carrion scavenging gastropods (Nassariidae, Buccinidae) in Princess Royal Harbour, Albany, Western Australia. Journal of Molluscan Studies, 69, 151-156.

Morton, B. \& Yuen, W.Y., 2000. The feeding behaviour and competition for carrion between two sympatric scavengers on a sandy shore in Hong Kong: the gastropod, Nassarius festivus (Powys) and the hermit crab, Diogenes edwardsii (De Haan). Fournal of Experimental Marine Biology and Ecology, 246, 1-29.

Navarette, S.A., 1996. Variable predation: effects of whelks on a mid-tidal successional community. Ecological Monographs, 66, 301-321.
Navarette, S.A. \& Menge, B.A., 1996. Keystone predation and interaction strength: interactive effects of predators on their main prey. Ecological Monographs, 66, 409-429.

Nickell, T.D. \& Moore, P.G., 1992a. The behavioural ecology of epibenthic scavenging invertebrates in the Clyde Sea area: laboratory experiments on attractions to bait in moving water, underwater TV observations in situ and general conclusions. Fournal of Experimental Marine Biology and Ecology, 159, 15-35.

Nickell, T.D. \& Moore, P.G., 1992b. The behavioural ecology of epibenthic scavenging invertebrates in the Clyde Sea area: laboratory experiments on attractions to bait in static water. Fournal of Experimental Marine Biology and Ecology, 156, 217-224.

Ponder, W.F., 1973. The origin and evolution of the Neogastropoda. Malacologia, 12, 295-338.

Ramsay, K., Kaiser, M.J. \& Hughes, R.N., 1998. Responses of benthic scavengers to fishing disturbances by towed gears in different habitats. Fournal of Experimental Marine Biology and Ecology, 224, 73-89.

Ramsay, K., Kaiser, M.J., Moore, P.G. \& Hughes, R.N., 1997. Consumption of fisheries discards by benthic scavengers utilization of energy subsidies in different marine habitats. Fournal of Animal Ecology, 66, 884-896.

Ruxton, G.D. \& Houston, D.C., 2004. Energetic feasibility of an obligate marine scavenger. Marine Ecology Progress Series, 266, 59-63.

Schoener, T.W., 1974. Resource partitioning in ecological communities. Science, New York, 185, 27-41.

Takashi, O., 2000. Marine mollusks in Japan. Tokyo: Tohai University Press.

Tan, K.S. \& Morton, B., 1998. The ecology of Engina armillata (Gastropoda: Buccinidae) in the Cape d'Aguilar Marine Reserve, Hong Kong, with particular reference to its preferred prey (Polychaeta: Serpulidae). Fournal of Zoology, 244, 391-403.

Taylor, J.D., 1976. Habitats, abundance and diets of muricacean gastropods at Aldabra Atoll. Zoological fournal of the Linnean Society, 59, 155-193.

Taylor, J.D., 1980. Diets and habitat of shallow water predatory gastropods around Tolo Channel, Hong Kong. In The malacofauna of Hong Kong and Southern China I. Proceedings of the first international workshop on the malacofauna of Hong Kong and Southern China, Hong Kong 1977 (ed. B Morton), pp. 163-180. Hong Kong: Hong Kong University Press.

Taylor, J.D., 1982. Diets of sublittoral predatory gastropods of Hong Kong. In the marine flora and fauna of Hong Kong and Southern China, Hong Kong, Proceedings of the first international marine biological workshop: the marine flora and fauna of Hong Kong and Southern China, Hong Kong 1980 (ed. B. Morton and C.K. Tseng), pp. 907-920. Hong Kong: Hong Kong University Press.

Taylor, J.D., 1984. A partial food web involving predatory gastropods on a Pacific fringing reef. Fournal of Experimental Marine Biology and Ecology, 74, 273-290.

Taylor, J.D., 1994. Sublittoral benthic gastropods from the southern waters of Hong Kong. In The malacofauna of Hong Kong and Southern China III. Proceedings of the third international workshop on the malacofauna of Hong Kong and the South China Sea, Hong Kong 1992 (ed. B. Morton), pp. 479-495. Hong Kong: Hong Kong University Press.

Taylor, J.D., 1998. Understanding biodiversity: adaptive radiations of predatory marine gastropods. In The marine biology of the South China Sea III. Proceedings of the third international conference on the marine biology of the South China Sea, Hong Kong 1996 (ed. B. Morton), pp. 187-206. Hong Kong: Hong Kong University Press.

Taylor, J.D. \& Morton, B., 1996. The diets of predatory gastropods in the Cape d'Aguilar Marine Reserve, Hong Kong. Asian Marine Biology, 13, 141-166. 
Taylor, J.D. \& Shin, P.K.S., 1990. Trawl surveys of sublittoral gastropods in Tolo Channel and Mirs Bay: a record of change from 1976-1986. In The marine flora and fauna of Hong Kong and Southern China II. Proceedings of the second international marine biological workshop: the marine flora and fauna of Hong Kong and Southern China, Hong Kong 1986 (ed. B. Morton), pp. 857-881. Hong Kong: Hong Kong University Press.

Tong, K.Y.L., 1986. The feeding ecology of Thais clavigera and Morula musiva (Gastropoda: Muricidae) in Hong Kong. Asian Marine Biology, 3, 163-178.
Vermeij, G.J., Leskinsky, H.A., Zipser, E. \& Vermeij, H.E., 1994. Diet and mode of feeding of the muricid gastropod Acanthinucella lugubris angelica in the northern Gulf of California. Veliger, 37, 214-215.

Submitted 28 July 2005. Accepted 10 November 2005. 